\title{
EKSISTENSI TRADISI PEMBUATAN GERABAH TRADISIONAL DALAM KAITANNYA DENGAN PELAKSANAAN UPACARA AGAMA HINDU DI DESA BANYUNING, KABUPATEN BULELENG
}

Oleh:

Dewa Nyoman Sucita

STKIP Agama Hindu Singaraja, Indonesia

Email: dewasucita58@gmail.com

\begin{abstract}
ABSTRAK
Penelitian deskriptif kualitatif ini bertujuan untuk mengungkap keberadaan pembuatan gerabah tradisional di desa Banyuning, yang mana saat ini sudah banyak peralatan sejenis dibuat dari berbagai bahan dasar. Untuk merampungkan penelitian ini digunakan berbagai metode antara lain: penentuan informan digunakan snowballing sampling, pengumpulan data digunakan metode (1) observasi, (2) wawancara dan (3) pencatat dokumen. Menganalisis data menggunakan model Miler dan Heberman. Berdasarkan analisis data diperoleh hasil penelitian sebagai berikut: (1) asal-usul berkembangnya pembuatan gerabah tradisional di Desa Banyuning sampai saat ini tidak diketahui secara pasti, sejak kapan berkembangnya pembuatan gerabah tersebut karena tidak didapatkan data tertulis sampai saat ini; (2) tradisi pembuatan gerabah tradisional di desa Banyuning terancam punah, karena merebaknya berbagai peralatan yang sejenis diciptakan manusia terbuat dari bahan lain dengan kualitas yang lebih unggul; (3) Para pekerja tidak dapat mempertahan kehidupan sehari-hari dari profesinya sebagai pengerajin gerabah tradisional, karena berbagai tantangan yang dialami dewasa ini, antara lain: sulitan pemasaran produk, sulitanya mencari bahan baku tanah, sumber daya manusia yang terbatas dan cuaca yang tidak menentu; dan (4) pemasaran terbatas pada pasar-pasar di lingkungan Kabupaten Buleleng.
\end{abstract}

Kata Kunci: Eksistensi, Gerabah Tradisional

\begin{abstract}
This qualitative descriptive study aimed at investigating the existence of traditional pottery making in Banyuning Village of which there are many other basic materials to make earthenware nowadays. Some methods were used in this study, such as: snowballing sampling for choosing the subjects of study, data collection using (1) observation, (2) interview and (3) documents collection. Data was analyzed using Miler and Heberman model. The results of this study are: (1) the origins of the development of traditional pottery making in Banyuning Village is uncertain because there is no written data obtained until now; (2) the tradition of traditional pottery making in Banyuning is threatened with extinction, due to the development of various similar equipment made from other materials with superior quality; (3) workers cannot maintain their profession as craftsmen of traditional pottery as their main income for daily life, due to various
\end{abstract}


Jurnal Widya Sastra Pendidikan Agama Hindu

Volume 3 Nomor 1 Tahun 2020

ISSN: $2656-7466$

challenges, such as: the difficulty of products marketing, the difficulty of finding raw materials, limited human resources and uncertain weather; and (4) the marketing is limited to markets in the Regency of Buleleng.

Keywords: existence, traditional pottery making

\section{PENDAHULUAN}

Agama Hindu tidak bisa dipisahkan dengan pelaksanaan upacara agama yang lebih dikenal dengan yadnya. Oleh karena, pelaksanaan yadnya merupakan salah satu bentuk implementasi dari ajaran agama Hindu itu sendiri. Yadnya merupakan salah satu kerangka dasar agama Hindu, dari tiga kerangka dasar yang ada, yakni tattwa, etika dan upcara (yadnya). Dari ketiga kerangka dasar ini justru upacara atau yadnya yang tampak secara kasat mata lebih dominan. Walaupun sesungguhnya dalam pelaksanaan yadnya itu sudah terkandung unsur yang lainnya baik tattwa maupun etika. Hal inilah yang menyebabkan dalam kehidupan beragama umat Hindu secara berkesinambungan melaksanakan upacara/yadnya, baik yang tergolong ke dalam Dewa Yadnya, Rsi Yadnya, Manusa Yadnya, Pitra Yadnya, maupun Bhuta yadnya.

Kita ketahui bahwa dalam melaksanakan upacara yadnya, umat Hindu menggunakan berbagai sarana dan prasarana, yang lebih dikenal dengan istilah upakara. Jadi dalam pelaksanaan upacara, umat Hindu akan menggunakan berbagai upakara (banten/sesajen) yang dibuat dari buah, daun, bunga, air dan api. Buah, daun, bunga, air dan api ditata sedemikian rupa hingga menjadi berbagai jenis banten seperti daksina, pejati, soda, pengambean, dapetan, taman pologembal, tetebasan, sesayut, jerimpen, penyeneng, perasita, caru dan sebagainya. Pembuatan banten di samping menggunakan sarana-sarana di atas, juga menggunakan prasarana penunjang yang terbuat dari kayu, bambu, besi, tembaga, perak, tanah bahkan ada yang terbuat dari batu. Prasana yang dimaksudkan dalam hal ini seperti wanci (dulang), kelakat, sanggah cucuk, tempeh, sok kasi, ngiyu, bokoran, tikeh, lesung, batu borean, senden, coblong dan lain-lain. Peralatan-peratan ini biasanya digunakan sebagai tempat banten, yang keberadaannya tidak dapat dipisahkan dengan banten itu sendiri. Artinya, setiap pembuatan banten dalam rangkaian upacara yadnya tentu akan memerlukan dan menggunakan peralatanperalatan penunjang ini. Banten tidak akan dapat dibuat tanpa kehadiran dari sarana- 
Jurnal Widya Sastra Pendidikan Agama Hindu

Volume 3 Nomor 1 Tahun 2020

ISSN: $2656-7466$

sarana penunjang ini. Ini menujukkan bahwa sarana prasarana penunjang ini keberadaannya sangat penting dalam kaitannya dengan pelaksanaan upacara yadnya dalam agama Hindu.

Salah satu peralatan yang digunakan dalam pelaksanaan upacara dalam agama Hindu adalah peralatan-peralatan yang terbuat dari tanah yang dikenal dengan sebutan gerabah, seperti paso/pane, payuk, coblong, caratan, senden (dulang tanah) dan lain-lain. Mengingat dalam setiap pelaksnaan upacara menggunakan peralatan-peralatan seperti ini, tentu harus ada yang memproduksiya, yang membuat dan menyediakan peralatanperalatan tersebut. Inilah kaiatan antara agama dengan aktivitas manusia, antara agama Hindu dengan kreativitas budaya dan tradisi yang dilakukan oleh umatnya sendiri. Artinya, pelaksanaan upacara atau yadnya yang dilakukan oleh umat Hindu dalam menjalankan ajarannya berdampak pada krativitas dan tradisi umatnya sendiri. Sepanjang umat Hindu melaksanakan upacara atau yadnya sepanjang itu peralatan-peralatan yang dibuat dari tanah (gerabah) seperti yang disebutkan di atas itu diperlukan. Ini berarti pula tradisi pembuatan paso/pane, payuk, coblong, caratan, senden dan lain-lain perlu dilestarikan.

Terkait dengan produksi peralatan-peralatan atau sarana prasarana upacara agama Hindu yang terbuat dari tanah (gerabah) khusus yang berada di Kabupaten Buleleng tentu tidak bisa dipisahkan dengan Desa Banyuning, Kabupaten Buleleng. Sebab, di Desa inilah tempatnya memproduksi gerabah tradisional ini. Pembuatan perlatan-peralatan upacara agama Hindu dari tanah ini telah dilakukan oleh warga Banyuning secara turuntemurun, sehingga aktivitas ini merupakan aktivitas yang berkelanjutan sejak dahulu sampai sekarang ini. Ia merupakan tradisi yang masih hidup sampai saat ini. Tradisi ini merupakan suatu pekerjaan atau profesi dari beberapa keluarga di desa Banyuning.

Peralatan yang dibuat dan digunakan oleh manusia dalam hidupnya baik untuk keperluan hidup sehari-hari maupun untuk keperluan ritual keagamaan akan mengalami perubahan-perubahan sesuai dengan perkembangan dan kemajuan pola pikir manusia itu sendiri. Suatu contoh cara berpakian, awalnya manusia berpakaian sangat sederhana hanya terbuat dari dedaunan dan hanya menutupi bagian tubuh tertentu, khususnya hanya pada bidang kemaluan manusia. Dalam perkembangan berikutnya pakaian dibuat dari 
Jurnal Widya Sastra Pendidikan Agama Hindu

Volume 3 Nomor 1 Tahun 2020

ISSN: $2656-7466$

kulit kayu. Sejalan dengan perkembangan otak manusia, manusia dapat membuat pakaian dari kapas atau kain dalam bentuk atau model selalu mengalami perubahan. Demikian pula dalam pembuatan sarana prasarana penunjang pelaksanaan upacara dalam agama Hindu mengalami perubahan-perubahan dari waktu ke waktu, sehingga peralatan yang digunakan oleh umat Hindu dalam upacara keagamaan dewasa ini sudah jauh berbeda dengan sepuluh tahun yang lalu. Dalam pelaksanaan upacara agama Hindu dewasa ini umat Hindu tidak hanya menggunakan peralatan-peratan penunjang dari tanah melainkan menggunakan berbagai peralatan dari bahan lain seperti plastik, perak, kuningan, viber dan lain-lain tentu dalam pembuatannya telah menggunakan teknologi yang tinggi. Peralatan-peralatan yang terbuat dari bahan-bahan inilah yang justru digunakan sekarang ini lebih banyak.

Dengan melihat kenyataan seperti itu tentu berdampak terhadap tradisi pembuatan Gerabah, khususnya tradisi pembuatan Gerabah Tradisional di desa Banyuning. Dengan berkembangnya peralatan-peralatan upacara dari bahan lain akan mempengaruhi pangsa pasar penjualan Gerabah Tradisional yang terbuat dari tanah. Dengan berkurangnya permintaan pasar, para pengrajin Gerabah Tradisional tidak akan dapat menggantungkan hidupnya dari profesi yang sudah bertahun-tahun mereka geluti, sehingga ada kemungkinan mereka akan meninggalkan profesinya dan beralih kepada profesi lain. Hal inilah yang menarik untuk diteliti..

Tujuan yang ingin dicapai dalam penelitian ini: 1). Untuk mengetahui asal-usul berkembangnya tradisi pembutan Gerabah Tradisional di desa Banyuning. 2). Untuk mengetahui keberadaan tradisi pembuatan Gerabah Tradisional dewasa ini saat banyaknya diciptakan sarana prasarana penunjang upacara agama Hindu yang terbuat dari bahan lain selain dari tanah 3). Untuk mengetahui pemasaran hasil produk kerajinan tradisi pembuatan Gerabah Tradisional dalam masa persaingan dengan produk peralatan pununjang upacara dari bahan lain. 4). Untuk mengetahui apakah para pengrajin Gerabah masih dapat mengandalkan penghsilannya dari pembuatan Gerabah Tradisional untuk kehidupannya sehari-hari.

\section{METODE PENELITIAN}


Jurnal Widya Sastra Pendidikan Agama Hindu

Volume 3 Nomor 1 Tahun 2020

ISSN: $2656-7466$

Penelitian ini termasuk penelitian deskriptif kualitatif. Dalam penelitian kualitatif terdapat hal-hal sebagai berikut: 1) data disikapi sebagai data verbal atau sebagai sesuatu yang dapat ditransposisikan sebagai data verbal; 2) diorientasikan pada pemahaman makna baik itu merujuk pada ciri, hubungan sistematika, konsepsi, kaidah dan abstraksi formulasi pemahaman; 3) mengutamakan hubungan secara langsung antara peneliti dengan yang diteliti dan 4) mengutamakan peran peneliti sebagai instrumen kunci. Penelitian kualitatif dilakukan dengan dua alasan. Pertama, karena sifat masalah itu sendiri yang mengharuskan menggunakan penelitian kualitatif. Kedua, karena penelitian yang dilakukan bertujuan untuk memahami apa yang tersembunyi di balik fenomena yang kadang kala merupakan sesuatu yang sulit untuk diketahui atau dipahami.

Penelitian kualitatif dilaksanakan karena adanya fenomena yang menarik di lapangan berupa masalah sosial, ketidakwajaran gejala sosial, dan ada sesuatu gejala yang sejalan dengan teori perubahan sosial. Fenomena ini kita dapatkan di desa Banyuning. Di desa ini ditemukan adanya gejala menurunnya pengrajin Gerabah Tradisional karena berbagai faktor perubahan dan kemajuan yang terjadi. Gejala ini tentu berdampak pada berbagai bidang kehidupan maupun pelaksanaan ritual Hindu. Mengingat fenomena ini terjadi di Desa Banyuning, maka lokasi inilah yang dipakai sebagai kancah penelitian.

Jenis data dalam penelitian ini adalah berupa informasi yang didapat dari beberapa informan dan juga berupa catatan dari beberapa sumber tertulis baik yang didapatkan di desa Banyuning maupun dari beberapa perpustakaan yang ada di Buleleng. Teknik digunakan menentukan jumlah informan adalah dengan snowballing sampling, walaupun banyak sedikitnya informan tidak menentukan akurat dan tidaknya penelitian ( Basrowi dan Sukidin, 2002:11). Dasar pertimbangan yang digunakan untuk memilih informan adalah: (1) orang yang bersangkutan memiliki pengalaman pribadi memadai tentang Gerabah tradisional atau para pangrajin gerabah, (2) usia yang bersangkutan telah dewasa, (3) orang yang bersangkutan sehat secara jasmani dan rohani, dan (4) orang yang bersangkutan memiliki pengetahuan yang luas tentan asal-usul dan perkembangan tentang tradisi pembuatan Gerabah di Desa Banyuning. Bertitik tolak dari hal ini, maka yang dijadikan informan dalam penelitian ini adalah para pangrajin Gerabah tradisional 
Jurnal Widya Sastra Pendidikan Agama Hindu

Volume 3 Nomor 1 Tahun 2020

ISSN: $2656-7466$

desa Banyuning, para pedagang Gerabah tradisional, para prajuru baik dinas maupun adat Banyuning dan tokoh-tokoh masyarakat Banyuning.

Dalam mengumpulkan data digunakan: (1) metode observasi, (2) metode wawancara/ interview dan (3) metode pencatat dokumen. Data yang terkumpul dianalisis dengan menggunakan model analisis data yang dikembangkan oleh Miler dan Heberman. Analisis data dengan model ini pada dasarnya dilakukan peneliti secara terus menerus mulai dari proses pengumpulan data. Pada dasarnya model analisis data ini mencakup tiga kegiatan yang bersamaan, yaitu: (1) reduksi data, (2) penyajian data, dan (3) penarikan kesimpulan (verifikasi).

\section{HASIL DAN PEMBAHASAN}

1. Asal-usul Berkembangnya Pembuatan Gerabah Tradisional di Desa Banyuning.

Asal-usul gerabah tradisional di desa Banyuning tidak diketahui secara pasti, kapan masyarakat Banyuning mulai membuat gerabah. Hal ini disebabkan karena sampai saat ini belum ditemukan data-data tertulis tentang Gerabah ini baik dalam bentuk catatan-catatan maupun prasasti. Para pengrajin hanya meneruskan secara turun-temurun. Diperkirakan masyarakat Banyuning membuat gerabah sezaman dengan pembuatan gerabah masyarakat Bali seperti di Banjar Basangtamiang, desa Kapal, Badung, Desa Pejaten Tabanan, Banjar Binoh, Ubung, dan Desa Tojan Kelungkung. Walaupun demikian ada tokoh masyarakat yang berpendapat bahwa perkembangan gerabah di Banyuning khususnya dan di Bali umumnya sudah mulai berkembang sejak zaman prasejarah, sebagaimana hasil-hasil penelitian menunjukkan bahwa gerabah telah dikenal oleh masyarakat Indonesia sejak zaman Prasejarah, sejalan dengan berkembangnya kebudayaan bercocok tanam. Gerabah adalah pendukung kebudayaan bercocok tanam, ya merupakan salah satu produk dari hasil mengolah tanah. Gerabah yang dihasilkan pada awalnya tentu yang terkait dengan peralatan hidup sehari-hari seperti kendi, tempayan, priyuk dan lain-lain yang banyak ditemukan di berbagai tempat di Indonesia seperti Kadenglebu, Banyuawangi; Kalapadua, Bogor; Kalapang dan daerah Minanga, Sulawesi dan lain-lain. Setelah berkembangnya agama Hindu, khususnya di Bali barulah 
Jurnal Widya Sastra Pendidikan Agama Hindu

Volume 3 Nomor 1 Tahun 2020

ISSN: $2656-7466$

berkembangnya gerabah-gerabah yang terkait dengan peralatan upacara agama Hindu seperti paso/pane, payuk, coblong, caratan, senden dan lain-lain .

\section{Keberadaan Tradisi Pembuatan Gerabah Tradisional Dewasa ini di Desa Banyuning}

Perkembangan ilmu pengetahuan dan teknologi dewasa ini bertambak pula pada peningkatan kualitas sumberdaya manusianya. Manusia yang menguasai ilmu pengetahuan dan teknologi yang maju akan dapat menghasilkan karya-karya atau budaya yang maju dan unggul pula. Dahulu, lebih-lebih semasih zaman prasejarah manusia hanya mampu membuat beberapa jenis gerabah seperti payuk, (alat menyimpan makan/daging), pulu, (alat menyimpan beras) dengan proses pembuatan yang sederhana mulai dari pengolahan tanah (tanah liat/tanah lempung), setelah tanah itu halus lalu diolah menjadi bentuk atau jenis barang yang diinginkan, lalu dilanjutkan dengan proses penjemuran di bawah terik matahari dan terakhir baru proses pembakaran. Dengan proses yang sederhana ini tentu produk yang dihasilkan juga sangat sederhana, tidak mengkilat seperti hasil kerajinan keramik yang dihasilkan manusia sekarang. Proses pembuatan gerabah tradisional di desa Banyuning sampai saat ini melalui proses yang sederhana ini, sehingga produk-produk yang dihasilkan juga sangat sederhana, baik dari segi jenis dan bentuk, maupun kualitasnya. Para pengrajin yang sekarang hanya menghasilkan beberapa jenis gerabah seperti payuk, pane, caratan, pot, coblong, dan alat-alat upacara lainnya yang tebuat dari tanah. Inilah yang menyebabkan keberadaan dan kelestarian pembuatan Gerabah trasional Banyuning terancam punah. Lebih-lebih belakangan ini manusia sudah dapat membuatan peralatan dan perlengkapan upacara dari berbagai bahan seperti plastik, perak, kuningan, kayu, viber dan lain-lain tentu dalam pembuatannya telah menggunakan teknologi yang tinggi. Peralatan-peralatan yang terbuat dari bahan-bahan inilah yang justru digunakan oleh umat Hindu sekarang ini lebih banyak. Misalnya sekarang umat Hindu di Bali tidak ada lagi yang menggunakan senden (dulang yang terbuat dari tanah), melainkan umat sudah menggunakan wanci/dulang yang terbuat dari kayu dan ada juga viber dengan kualitas yang jauh lebih tinggi, karena penuh dengan ukiran dan dicat dengan prade. Hal inilah yang menyebabkan sekarang ini para pengrajin tidak lagi membuat senden ini. Dalam perkembangan berikutnya tentu akan terjadi pula 
Jurnal Widya Sastra Pendidikan Agama Hindu

Volume 3 Nomor 1 Tahun 2020

ISSN: $2656-7466$

pada jenis gerabah yang lainnya, sehingga keberadaan gerabah tradisional banyuning keberadaannya diambang kepunahan.

3. Kebertahanan Para Pengrajin Gerabah Tradisional untuk Kehidupannya Sehari-hari.

Masa kejayaan pembuatan gerabah tradisional di Banyuning berlangsung hampir 20 tahun mulai tahun 1960 sampai dengan tahun 1980. Pada masa itu, di Banyuning terutama di Banyuning Tengah hampir sebagian rumah tangga menekuni profesi pokok keluarga sebagai pengerajin gerabah. Dalam satu keluarga, baik anak-anak, remaja, dan orang tua bersama-sama sebagai pengerajin gerabah. Oleh karena banyaknya pengarajin pada saat itu, maka dibentuklah kelompok pengarajin gerabah dengan sebutan atau nama Perkumpulan Payuk Kedas. Perkumpulan ini dibentuk dengan harapan agar tidak terjadi persaingan yang tidak sehat di antara pengrajin. Pada saat jaya-jaya ini para pengerajin tidak susah memasarkan hasil kerjanya. Mereka hanya berusaha menghasil produk di rumahnya masing-masing para pedagang yang menjadi laganannya akan mencarinya sendiri. Di samping itu, masyarakat Banyuning yang tidak sebagai pengrajin banyak menjadi pedagang gerabah di pigiran jalan Gempol, di kawasan Banyuning Tengah. Kondisi sekarang ini telah terbalik dengan era 1980an. Dengan banyaknya saingan dari pengrajin-pengrajin sejenis dengan bahan baku lain dan dengan kualitas yang bernilai tinggi maka para pengerajin gerabah tradisional mengalami kesulitan memasarkan barang dagangannya. Banyak hasil karyanya tidak laku di pasaran. Ini menyebabkan para pengerajin gulung tikar, mereka mengalihkan profesikan ke bidang lain seperti petani, peternak, tukang, buruh, nelayan, ngojek, tukang parkir, buruh pasar dan lain-lain. Ini pula yang menyebabkan secara berangsur-angsur jumlah pengerajin gerabah terus semakin berkurang, yang pada mulanya sebagian masyarakat sebagai pengerajin, sekarang hanya dua keluarga yang masih menekuni sebagai pengerajin gerabah,yakni keluarga Made Suarsana dan keluarga Nengah Napastika yang terletak di jalan Gempol, gang Masula-Masuli. Bapak Made Suarsana mempekerjakan tenaga sebanyak 10 orang sedangkan bapak Nengah Napastika mepekerjakan tenaga kerja sebanya 7 orang. Semua tenaga kerja ini adalah kerabat dan anggota keluarganya sendiri. Ini berarti profesi sebagai pengerajin gerabah tradisional tidak menarik lagi karena tidak menjanjikan 
Jurnal Widya Sastra Pendidikan Agama Hindu

Volume 3 Nomor 1 Tahun 2020

ISSN: $2656-7466$

kehidupan yang layak di kemudian hari, sehingga mereka mengalihkan profesinya ke bidang lain.

Sejalan dengan berkurangnya pengerajin gerabah di desa Banyuning, tampaknya minat para generasi mudanya juga sangat rendah. Mereka tidak lagi mengidolakan profesi sebagai pengerajin gerabah melainkan mencibirnya. Para generasi mudanya lebih banyak yang becita-cita pada dunia lain khususnya dalam dunia pariwisata, sebagai pegawai hotel, gaeding/pemandu wisata, pegawai restorant, melanjutkan studi/kuliah dan lain-lain. Inilah yang menyebabkan sekarang ini masyarakat yang tetap menjadi pengerajin gerabah adalah masyarakat yang telah berumur. Mereka telah berumur antara 30 tahun ke atas. Tidak ada tenaga pengerajin yang berumur 10 atau 15 tahun. Ini sangat mengkhawatir pada tahun-tahun mendatang kemampuan dan keterampilan membuat gerabah tradisional di Banyuning tidak diturunkan secara natural seperti zaman dahulu dan akan dikhawatirkan keterampilan membuat gerabah akan punah.

Ada berbagai tantangan yang dialami oleh pengerajin gerabah tradional Banyuning antara lain:

1). Persaingan yang Ketat

Sejak dahulu dalam dunia usaha persaingan itu telah ada, baik bersifat intern (lokal) maupun antar luar daerah; lebih-lebih dalam perkembangan usaha dewasa ini di mana persaingan itu semakin ketat. Hidup dan berkembangnya sebuah usaha apabila dapat memenangkan sebuah persaingan. Persaingan dalam bidang apa? Tentu dalam berbagai aspek, baik dalam sumber daya manusia pekerjanya, kualitas barang yang dihasilkan, promosinya, pemasarannya dan lain-lain. Dilihat dari berbagai sudut tampaknya pengerajin dan produk gerabah tradisional Banyuning sulit untuk memenangan persaingan tersebut, karena kalah dengan berbagai produk yang dihasilkan belakangan ini.

2). Bahan Baku

Bahan baku utama dari pembuatan gerabah ini adalah tanah liat (tanah lempung) di samping bahan bakar seperti jerami. Tidak semua jenis tanah dapat dijadikan sebagai dasar pembuatan gerabah, hanya tanah liat atau tanah lempung yang dapat dijadikan bahan dasar pembuatan gerabah ini. Pada zaman dahulu para pengerajin Banyuning 
Jurnal Widya Sastra Pendidikan Agama Hindu

Volume 3 Nomor 1 Tahun 2020

ISSN: $2656-7466$

tidak kesulitan mencari tanah liat ini, karena areal di sekitar gang Masula-Masuli masih kosong, di mana tanah di sekitar ini sebagian besar tanah liat sehingga cocok sebagai bahan membuat gerabah. Namun sekarang ini sudah penuh dengan pemukiman (perumahan) baru sehingga para pengerajin kesulitan untuk mendapatkan bahan baku. Para pengerajin harus beli ke desa-desa tetangga seperti Pengelatan, Padangkeling, Sudaji, Alasangker dan lain-lain.

3). Sumber Daya Manusia

Pada masa jayanya gerabah tradisional, para pengerajin gerabah mulai dari anak-anak, para remaja maupun orang dewasa. Pada saat itu semua orang bangga menjadi pengerajin gerabah, karena menjajikan kehidupan yang lebih baik menjadi pengerajin gerabah. Namun sekarang, profesi sebagai pengerajin gerabah tidak menggiurkan lagi, karena tidak dapat menjadi kehidupan yang lebih baik seperti profesi-profesi lainnya seperti pegawai baik negeri maupun swasta, pedagang di pasar, bekerja di dunia pariwisata dan lain-lain, sehingga generasi muda sekarang tidak mau meneruskan profesi pengerajin gerabah ini. Para pengerajin gerabah yang ada sekarang ini sebagian besar adalah para orang tua dengan tingkat pendidikan hanya Sekolah Dasar. Apabila ada yang berumur muda atau anak-anak itu hanya keluarga sendiri seperti ponakan, dan cucu. Mereka ini hanya sebagai pekerja sampingan yang sifatnya hanya membantu saja setelah lepas dari sekolah, sehingga sumberdaya manusia pengerajin yang masih ada sekarang ini sangat terbatas baik dari kualitas maupun kuantitasnya.

\section{4). Cuaca}

Salah satu kendala yang dihadapi pengerajin Banyuning dewasa ini adalah masalah cuaca. Sebab, proses pembuatan gerabah disertai dengan pengeringan matahari. Dewasa ini keadaan cuaca tidak seperti dahulu sesuai dengan dewasa yang ada. Pada musim hujan, memang hujan, pada musim kemarau memang sulit mencari hujan. Namun sekarang sering terjadi pada musim hujan tidak ada hujan, dan sebaliknya pada pada musim kemarau sering terjadi hujan. Hal seperti ini akan berpengaruh besar pada pembuatan gerabah. Para pengerajin biasanya bekerja pada saat kemarau untuk bisa menjemur produk yang dihasilkan. Apabila pada saat penjemuran ini selalu hujan 
Jurnal Widya Sastra Pendidikan Agama Hindu

Volume 3 Nomor 1 Tahun 2020

ISSN: $2656-7466$

tentu akan menghasil karya tidak berkualitas bahkan bisa menghancurkan produk yang sudah dihasilkan.

4. Pemasaran Gerabah Tradisional dalam Masa Persaingan dengan Produk Peralatan Upacara dari Bahan lain

Hasil produk yang dihasilkan oleh pengerajin akan berjalan lancar kalau konsumen secara berkelanjutan memerlukan. Dengan banyak produk-produk peralatan lain yang dihasilkan dari bahan lain yang berkualitas unggul yang dihasilkan pesaing, maka jenis-jenis peralatan yang dihasilkan oleh pengerajin tradisional ditinggalkan. Dahulu sedang tingginya permintaan pengerajin tidak menjajakan hasil karya kepada pedagang di pasar, melainkan mereka yang mencari ke rumah pengerajin. Pedagang yang datang sampai pedagang yang berasal dari luar Kabupaten Buleleng. Sekarang ini pengerajinlah yang menjajakan hasil produknya ke pedagang di pasar-pasar sekitar Buleleng seperti pasar Anyar, pasar Banyuasri, pasar Buleleng, pasar Banjar dan pasar Seririt.

\section{KESIMPULAN}

Berdasarkan uraian hasil penelitian di atas, maka dapat disimpulkan sebagai berikut:

1. Asal-usul berkembangnya pembuatan gerabah tradisional di Desa Banyuning sampai saat ini tidak diketahui secara pasti, sejak kapan berkembangnya pembuatan gerabah ini karena tidak didapatkan data tertulis sampai saat ini. Para pengerajin sekarang tidak mengetahui siapa tokoh leluhurnya yang memprakarsai pertama yang membuatan gerabah ini, di mana beliau belajar membuat gerabah. Mereka hanya meneruskan secara turun temurun saja.

2. Era sekarang sudah banyak tercipta barang-barang sejenis dari bahan lain yang kualitasnya jauh lebih unggul, baik dari segi kekuatannya (ketahanannya), modelnya, estetisnya (keindahan ukirannya) dan lain-lain, sehingga produkproduk dari pembuatan gerabah Banyuning kalah bersaing di pasaran. Akibatnya para pengerajin gerabah Banyuning semakin tahun akan semakin berkurang. 
Diprediksi ke depan tradisi pembuatan gerabah tradisional di desa Banyuning terancam punah. Buktinya sekarang ini hanya dua keluarga yang masih bertahan menekuni pembuatan gerabah tradisional ini.

3. Dengan kalahnya bersaing serta sulitnya memasarkan gerabah tradisional Banyuning, berdampak besar terhadap para pengerajinnya. Para pekerja tidak dapat mempertahan kehidupannya sehari-hari dari profesinya sebagai pengerajin gerabah tradisional. Untuk bertahan hidup mereka harus beralih profesi kepada biadang profesi yang lain. Di samping itu berbagai tantangan yang dialami pengerajin dewasa ini, antara lain: persaingan yang semakin ketat, sulitanya mencari bahan baku tanah, sumber daya manusia yang terbatas dan cuaca yang tidak menentu.

4. Wilayah pemasaran hasil karya pengerajin gerabah Banyuning sekarang terbatas pada pasar-pasar di lingkungan Kabupaten Buleleng antara lain pasar Anyar, pasar Banyuasri, pasar Buleleng, pasar Banjar dan pasar Seririt. Sekarang ini Kabupaten lain di Bali sudah ada pengerajin gerabahnya atau sudah memliki pengerajin lain yang menghasilkan produk-produk yang sejenis dengan kualitas yang lebih unggul, akibatnya para pengerajin gerabah Banyuning tidak dapat memasarkan hasil karya keluar Kabupaten Buleleng.

\section{DAFTAR PUSTAKA}

Agus Salim, (Penyunting) (2001). Teori dan Paradigma Penelitian Sosial (dari Denzin Guba dan Penerapannya), Penerbit: PT. Tiara Wacana Yogyakarta.

Alwasilah, A. Chaedar (2002). Pokoknya Kualitatif, Dasar-dasar Merancang dan Melakukan Penelitian Kualitatif, Penerbit: Pt Dunia Pustaka Jaya dan Pusat Studi Sunda, Jakarta.

Andi Prastowo, S.Pd.I, M.Pd.I (2011) Memahami Metode-Metode Penelitian, Suatu Tinjauan Teoritis \& Praktis; Penerbit: AR Ruzz Media, Yogyakarta.

Basrowi, M.Pd Dr. \& Dr. Suwandi, M.Si (2008) Memahami Penelitian Kualitatif; Penerbit: Rineka Cipta, Jakarta. 
Burhan Bungin (Ed) (2011) Metodelogi Penelitian Kualitatif, Aktualisasi Metodologis

ke Arah Ragam Varian Kontemporer, Penerbit: PT Rajagrapindo Persada, Jakarta.

Dja'man Satori, MA. Prof. Dr. \& Dr. Aan Komariah, M.Pd (2012) Metodelogi Penelitian Kualitatif; Penerbit: Alfabeta Bandung.

Drama Putra, I Nyoman (Editor). (2004). Bali Menuju Jagadhita: Aneka Perspektif, Penerbit: Pustaka Balipost, Denpasar.

Dasim Mathar, MA. DR. H. Moch. (2005). Sejarah, Teologi dan Etika, Agama-agama. Penerbit: Dian/Interfidei, Yogyakarta.

George Ritzer \& Douglas J. Goodman (2004) Teori Sosiologi Modern; Penerbit: Kencana Prenada

Gunadha, M.Si, Prof. Dr. Ida Bagus (2008-2009), Pemberdayaan Desa Pakraman, Sebagai Strategi Kebertahanan Adat, Budaya dan Agama Hindu Bali. Pembinaan Desa Pekraman, Kerja sama UNHI Denpasar \& Kanwil Departemen Agama Propinsi Bali.

Kutha Ratna, SU. Prof. Dr. Nyoman (2010) Metodelogi Penelitian Kajian Budaya dan Ilmu Sosial Humaniora pada Umumnya, Penerbit: Pustaka Pelajar, Yogyakarta.

Moleong, MA. Dr. Lexy J. (1993). Metodologi Penelitian Kualitatif, Penerbit: PT. Remaja Rosdakarya, Bandung.

Narwoko J. Dwi \& Bagong Suyanto (ed) (2006) Sosiologi Teks Pengantar dan Terapan; Penerbit: Kencana Pranada Media Group, Jakarta.

Siagian, Dra. Seno Harbangan, (1989) Agama-Agama di Indonesia (Cetakan Ke-II), Penerbit: Catya Wacana, Semarang.

Simpen, AB. Wayan (1986). Adat Kuna, Catur Desa (Tiga Wasa, Sidatapa, Pedawa, Cempaga). Penerbit: -

Sri Arwati, Dra. Ni Made (2005) Perwujudan Upakara untuk Upacara Agama Hindu; Penerbit : -

Suamba, Ida Bagus Putu (Alih Bahasa) (1996) Yajna Basis Kehidupan (Sebuah Canang Sari); Penerbit: PT Mabhakti Denpasar 
Suasthawa Dharmayuda, SH. I Made (1995). Kebudayaan Bali, Pra Hindu, Masa Hindu dan Pasca Hindu, Penerbit: CV. Kayumas Agung, Denpasar.

Sudarsana,MBA.MM. Drs. I.B.Putu (2000). Ajaran Agama Hindu Manifestasi Sang Hyang Widhi, Penerbit: Yayasan Dharma Acarya, Percetakan Mandara sastra, Denpasar.

(1998) Ajaran Agama Hindu, Filsafat Yadnya; Penerbit: Yayasan Dharma Acarya Percetakan Mandara Sastra, Denpasar.

(2001) Ajaran Agama Hindu (Dharmaning Paebatan) Dharma Caruban;

Penerbit: Yayasan Dharma Acarya Percetakan Mandara Sastra, Denpasar.

Sudikan,MA. Dr. Setya Yuwana (2001) Metode Penelitian Kebudayaan, Penerbit: Unesa Unipress bekerjasama dengan Citra Wacana, Surabaya.

Sugeng Pujilaksono. (2006). Petualangan Antropologi, Sebuah Pengantar Ilmu Antropologi, Pnerbit: UPT. Penerbitan Universitas Muhammadiyah, Malang.

Sutaba, I Made (1980) Prasejarah Bali, Penerbit: B.U Yayasan Purbakala Bali.

Team Penyusun, (1985/1986). Sejarah Perkembangan Agama Hindu di Bali, Penerbit: Proyek Penyuluhan Agama dan Penerbitan Buku Agama (1985/1986), Pemerintah Daerah Tingkat I Bali, Denpasar.

Team Penyusun, (1996) Catur Yadnya, Bhuta, Manusa, Pitra, Dewa; Penerbit: Upada Sastra, Denpasar.

Tim Penyusun, (2005). Pedoman Pembinaan Lembaga Keagamaan Hindu, Penerbit: Paramita, Surabaya.

Triguna, Ida Bagus Gede Yudha, (2001). Mengapa Bali Unik; Penerbit: Pustaka Jurnal Keluarga, Jakarta.

--------- (2001). Strategi Hindu; Penerbit: Pustaka Jurnal Keluarga, Jakarta.

PaEni, Mukhlis (editor) (2009) Sejarah Kebudayaan Indonesia (Relegi dan Falsafah); Penerbit: PT Rajagrafindo Persada, Jakarta.

Pendit, Nyoman S. Sri Chandrasekharendra Saraswati (1993). Aspek-aspek Agama Hindu, Seputar Weda dan Kebajikan. Penerbit: Pustaka Manik Geni, Jakarta.

Pendit, Nyoman S. (1995). Hindu Dalam Tafsir Modern, Penerbit : Yayasan Dharma Naradha, Denpasar. 
Jurnal Widya Sastra Pendidikan Agama Hindu

Volume 3 Nomor 1 Tahun 2020

ISSN: $2656-7466$

Purwita, Drs. Ida bagus Putu, (1984). Desa Adat dan Banjar di Bali, Penerbit: Percetakan Kawi Sastra, Denpasar.

Wiana, Ketut (1995) Yajna dan Bhakti Dari Sudut Pandang Hindu; Penerbit: PT Pustaka Manik Geni Denpasar.

Wijayananda, Empu Jaya (2003) Tetandingan Lan Sorohan Bebanten; Penerbit Paramita, Surabaya. 